\title{
Program "KOMPAK" untuk Meningkatkan Kualitas Hidup Ibu Pasien Kanker Anak
}

\author{
Anak Agung Ayu Ratna Paramita ${ }^{1}$ E Sofia Retnowati ${ }^{2}$ \\ 1,2Fakultas Psikologi Universitas Gadjah Mada
}

\begin{abstract}
Cancer in children affects not only the patient but for the parents. Parents who have a child with cancer, experience psychological burdens manifested in confusion, shock, rejection, exhaustion, anxiety, and worry. If not handled properly, these symptoms will make them experience stress. It can affect their health quality of life and reduce their ability to accompany child with cancer. Whereas parents health condition greatly affect the health condition of patients with cancer. This study aimed to improve the quality of life of parents who have a child with cancer by providing "KOMPAK" program. Participants from this study were 5 mothers of child with cancer. The research method used the one group pretest-posttest design. The analysis used Wilcoxon signed-rank non-parametric test. Results showed that there was a significant improvement in the quality of life in mothers of children with cancer $Z=-2.023$ and $p=0.043$ ( $p$ $<0.05)$. These results showed that "KOMPAK" program could improve their quality of life.
\end{abstract}

Keyword: child with cancer; kompak; mother of children with cancer; quality of life

Abstrak. Kanker pada anak memberikan dampak tidak hanya bagi pasien tapi bagi orang tua. Para orang tua mengalami beban psikologis yang termanifestasi dalam kebingungan, shock, penolakan, kelelahan, cemas, dan khawatir. Keluhan yang dialami para orang tua apabila tidak ditangani dengan baik akan membuat para orang tua mengalami stres. Stres yang mereka alami dapat memengaruhi kualitas hidup mereka dan penurunan kualitas pendampingan. Padahal kondisi kesehatan orang tua sangat berpengaruh terhadap kondisi kesehatan pasien. Penelitian ini bertujuan untuk meningkatkan kualitas hidup kesehatan orang tua dengan memberikan Program "KOMPAK". Partisipan dari penelitian ini adalah 5 orang ibu pasien kanker anak. Metode penelitian yang digunakan adalah the one group pretest-posttest design. Analisis yang digunakan untuk menguji hipotesis yaitu uji non-parametrik signed-rank Wilcoxon. Hasil menunjukkan bahwa terjadi peningkatan kualitas hidup yang signifikan pada ibu pasien kanker anak $Z=-2,023$ dan $p=0,043(p<0,05)$. Hasil ini menunjukan bahwa program "KOMPAK" mampu meningkatkan kualitas hidup ibu pasien kanker anak.

Kata kunci: ibu pasien kanker anak; kanker anak; kualitas hidup; program kompak

Kanker bisa diderita oleh siapa saja begitu juga anak-anak. Menurut data yang yang diperoleh melalui $\mathrm{WHO}$, setiap tahunnya angka kejadian kanker anak meningkat

${ }^{1}$ Korespondensi mengenai artikel ini dapat dilakukan melalui nanaparamita20@yahoo.com

2atau sofi 53@ugm.ac.id mencapai 130 kasus. Kanker yang dialami oleh anak memiliki proses pengobatan yang relatif lama. Proses pengobatan yang dijalani oleh anak, dapat menimbulkan beberapa dampak bagi perkembangan fisik, emosional dan sosialnya (Lambrini, 
Christos, Alexandros, \& Aikaterini, 2015). Penyakit kanker yang dialami oleh anak juga memiliki dampak pada keluarga terutama orang tua anak tersebut (Lähteenmäki, Sjöblom, Korhonen, \& Salmi ,2004; Wong \& Chan, 2006; Awasthi \& Kuhu, 2017; LeSeure \& Chongkham-Ang, 2015). Menurut Brown (2006), saat anak-anak telah terdiagnosis kanker para orang tua nantinya akan menghadapi berbagai tantangan dalam melanjutkan kehidupan mereka.

Orang tua dari pasien kanker anak tanpa disadari merupakan sosok yang memiliki banyak permasalahan, baik dari segi kesehatan fisik (Khoury et al., 2013) maupun dari segi psikologis (Lähteenmäki, et al., 2004; Wong \& Chan, 2006; Awasthi \& Kuhu, 2017; LeSeure \& Chongkham-Ang, 2015). Kondisi orang tua yang rentan mengalami tekanan dapat menyebabkan terjadinya stres pengasuhan yang merupakan manifestasi dari rasa kecemasan dan ketegangan yang berhubungan dengan peran orang tua atau interaksi antara orang tua dan anak (Abidin dalam Ahern, 2005). Dampak yang disebabkan oleh stres pengasuhan yang tinggi dapat membuat orang tua merasa kelelahan, penurunan kesehatan fisik, merasa tidak puas dalam menjalankan tugas sebagai orang tua dan kurang harmonisnya hubungan antara orang tua dan anak (Lestari, 2012).

Dibandingkan dengan ayah, ibu memiliki stres yang lebih tinggi yang dapat membuat kualitas hidupnya mengalami penurunan (Sloper, 2000; Frank, Brown, Blount, \& Bunke, 2001; Dardas \& Ahmad, 2014; Pisula \& Porębowicz-Dörsmann, 2017). Dardas dan Ahmad (2014), menemukan bahwa stres pengasuhan memengaruhi kualitas hidup pada orang tua terutama ibu sebagai pendamping utama. Ini dibuktikan pula dalam penelitian yang dilakukan oleh
Nayak, George, Vidyasagar, dan Kamath (2014) yang menunjukkan adanya korelasi antara stres dan kualitas hidup terutama pada domain kesehatan fisik. Stres pengasuhan yang tinggi berhubungan dengan berkurangnya kemampuan untuk mengatur emosi, kognisi dan perilaku. Hal ini menyebabkan pengolahan informasi melambat, mudah marah, dan perilaku terburu-buru sehingga berdampak pada kualitas hidup. Stres yang dialami orang tua melibatkan ketegangan psikologis dan fisik selama periode waktu yang panjang dan memiliki kapasitas untuk memengaruhi berbagai bidang kehidupan orang tua, juga sering disertai dengan tingkat kualitas hidup yang rendah (Dardas \& Ahmad, 2014). Padahal kondisi kesehatan caregiver yang dijalani orang tua sangat berpengaruh terhadap kondisi kesehatan pasien. Oleh karena itu, penting memberikan intervensi psikologi kepada para orang tua pasien kanker anak terutama pada ibu untuk meningkatkan kualitas hidupnya.

Berdasarkan penelitian yang pernah dilakukan oleh Wong dan Chan (2006) tentang caregiver kanker, merekomendasikan adanya aktivitas dukungan kelompok sesama caregiver sebagai salah satu bentuk intervensi yang dapat diberikan kepada orang tua pasien kanker. Salah satu intervensi psikologis yang dapat diberikan kepada ibu pasien kanker anak yaitu program kelompok dukungan. Kelompok dukungan sebagai bentuk intervensi bagi para orang tua yang anaknya mengidap penyakit kanker. Pada penelitian sebelumnya, Swastiningsih (2009) menggunakan intervensi ini untuk menurunkan stres para orang tua pasien kanker. Hasil penelitiannya membuktikan bahwa program kelompok dukungan mampu menurunkan stres orang tua pasien 
kanker. Peneliti akan menggunakan modul yang telah disusun sebelumnya oleh Swastiningsih (2009) untuk melihat tidak hanya terjadinya penurunan stres pada orang tua pasien kanker tetapi juga ingin melihat apakah dengan pemberian program mampu meningkatkan kulitas hidup orang tua khususnya ibu pasien kanker anak. Berdasarkan hasil penelitian sebelumnya, terdapat beberapa keterbatasan penelitian yang terjadi di lapangan. Hal inilah yang melandasi peneliti untuk melakukan sedikit modifikasi terhadap isi materi yang diberikan, instruksi, meniadakan aktivitas senam otak dan lebih fokus memberikan latihan relaksasi pernapasan dan relaksasi otot. Peneliti kemudian merumuskan kembali modul kelompok dukungan tersebut dan mengganti nama modul menjadi Program "KOMPAK" yang merupakan akronim dari Dukungan Kelompok Orang Tua Pasien Kanker Anak. Tujuan dari program ini adalah memberikan dukungan kepada para ibu pasien kanker anak sehingga stres pengasuhan yang dialami menjadi menurun dan kualitas hidupnya mengalami peningkatan.

\section{Metode}

\section{Partisipan}

Partisipan pada penelitian ini terdiri dari 5 orang ibu pasien kanker anak dengan rentang usia 24 tahun hingga 43 tahun yang dipilih dengan menggunakan metode purposive sampling berdasarkan kriteria/ inklusi yaitu memiliki anak yang menderita kanker usia 2 sampai 12 tahun dengan minimal masa perawatan selama 2 minggu, pernah menempuh pendidikan formal, dan bersedia berpartisipasi dalam penelitian.

\section{Prosedur penelitian}

Penelitian dilaksanakan di salah satu rumah sakit di Yogyakarta. Pelaksanaan penelitian dilakukan di salah satu ruang bermain yang terletak di dalam bangsal rawat inap kanker anak. Ruangan tersebut dapat digunakan oleh peneliti karena lokasinya yang dekat dengan bangsal, tertutup dan ber-AC sehingga nyaman untuk dijadikan tempat pertemuan. Pemberian program "KOMPAK" dilakukan sebanyak 3 kali pertemuan mulai tanggal 28 Juni 2018 sampai 3 Juli 2018 dengan durasi masingmasing pertemuan selama 120 menit.

Program "KOMPAK" diberikan oleh seorang fasilitator dan didampingi oleh dua orang observer. Fasilitator yang digunakan pada intervensi ini merupakan psikolog yang memiliki pengetahuan dan pengalaman tentang penyakit kanker pada anak. Observer yang digunakan pada intervensi ini merupakan mahasiswa Magister Psikologi Profesi yang telah lulus mata kuliah observasi. Materi yang diberikan kepada fasilitator adalah modul program "KOMPAK", sedangkan materi yang diberikan kepada observer adalah panduan observasi. Peneliti memberikan pembekalan kepada fasilitator dan observer sebelum penelitian dilakukan.

\section{Modul}

Perlakukan yang diberikan kepada partisipan yaitu memberikan modul program "KOMPAK" yang hasil dari modifikasi dari modul yang sebelumnya yaitu modul kelompok dukungan. Modifikasi dilakukan berdasarkan hasil penelitian sebelumnya yang memiliki beberapa keterbatasan. Bentuk modifikasi yang peneliti lakukan dengan menambahkan instruksi, materi yang akan diberikan, dan peneliti meniadakan aktivitas 
senam otak karena dirasa kurang relevan terhadap tujuan terapi.

Bentuk pelaksanaan program "KOMPAK" antara lain melibatkan kegiatan pemberian psikoedukasi, sharing, relaksasi dan keterampilan pemecahan masalah. Validitas yang diterapkan pada modul terdiri dari validitas isi dan validitas empiris. Berdasarkan hasil penilaian ahli diperoleh nilai Aiken $V$ yang bergerak antara 0,83 0,91 , dengan rerata sebesar 0,88 . Selanjutnya, masukan dari para rater menjadi pertimbangan peneliti untuk melakukan perbaikan dan penyesuaian modul untuk mencapai tujuan yang diharapkan dalam penelitian ini.

\section{Instrumen}

Pengukuran pra-perlakuan dan pascaperlakuan menggunakan dua jenis skala yaitu The Caregiver Oncology Quality of Life (CarGoQoL) yang telah diterjemahkan dan dimodifikasi ke dalam bahasa indonesia untuk mengukur kualitas hidup (Minaya et al., 2012; Winarsih, 2015) dan Parenting Stress Index (PSI) yang telah diterjemahkan dan dimodifikasi ke dalam bahasa Indonesia untuk mengukur stres pengasuhan (Dardas \& Ahmad, 2013; Hidayati, 2013. Kuesioner CarGoQoL telah teruji validitas dan reliabilitasnya dengan nilai koefesien korelasi $(r=0,002-0,866)$ serta nilai alpha Cronbach 0,950 (Winarsih, 2015). Validitas dari skala Parenting Stress Index (PSI) dapat dilihat dari nilai koefisien korelasi item $(r=$ 0,268 - 0,689) dan reliabilitas skala dilihat dari nilai alpha Cronbach sebesar 0,93. yang artinya aitem pada skala stres pengasuhan dapat dikatakan valid dan reliabel.

\section{Analisis}

Penelitian ini mnggunakan metode penelitian kuantitatif dengan desian penelitian yang digunakan yaitu the onegroup pretest-posttest design. Pengujian hipotesis dilakukan dengan menggunakan pendekatan statistik non-parametrik (distribution free statistics) berupa uji signedrank Wilcoxon, untuk melihat perbedaan skor pra-perlakuan dan pasca-perlakuan dalam sebuah kelompok. Analisis lain yang digunakan untuk melengkapi data adalah analisis deskriptif. Analisis ini berupa data wawancara dan observasi yang diperoleh dari partisipan sebelum, selama dan sesudah perlakuan diberikan.

\section{Hasil}

\section{Uji statistik Parenting Stress Index}

Cek manipulasi dilakukan dengan memberikan Parenting Stress Index kepada partisipan sebagai bukti bahwa setiap kondisi yang diciptakan oleh peneliti memang sudah tercapai. Peneliti memasukan skor mentah pretest dan posttest ke dalam bentuk tabel untuk melihat perbedaan mean dari skor mentah pretest dan posttest pada Tabel 1 .

Pada Tabel 1 dapat dilihat terjadi penurunan rata-rata skor stres pengasuhan dari 99,8 menjadi 85,2. Perubahan skor stres pengasuhan partisipan sebelum dan sesudah perlakuan dapat dilihat pada Gambar 1.

Berdasarkan hasil cek manipulasi diketahui bahwa terdapat perubahan skor pada partisipan sebelum dan sesudah pemberian program "KOMPAK". Peneliti kemudian melakukan uji statstik dengan melakukan uji Wilcoxon signed-rank test. Hasil menunjukan terjadi penurunan skor stres pengasuhan yang signifikan pada partisipan setelah mengikuti program "KOMPAK", dengan nilai $Z=-2,032, p=$ $0,042(p<0,05)$. Hal ini berarti terdapat pe- 
Tabel 1.

Hasil Pretest dan Posttest Skor Parenting Stress Index

\begin{tabular}{ccc}
\hline \multirow{2}{*}{ Inisial } & \multicolumn{2}{c}{ Skor Parenting Stress Index } \\
\cline { 2 - 3 } & Pretest & Posttest \\
\hline KF & 91 & 80 \\
KW & 116 & 103 \\
KM & 109 & 88 \\
KN & 94 & 81 \\
KD & 89 & 74 \\
\hline Mean & $\mathbf{9 9 , 8}$ & $\mathbf{8 5 , 2}$ \\
\hline
\end{tabular}

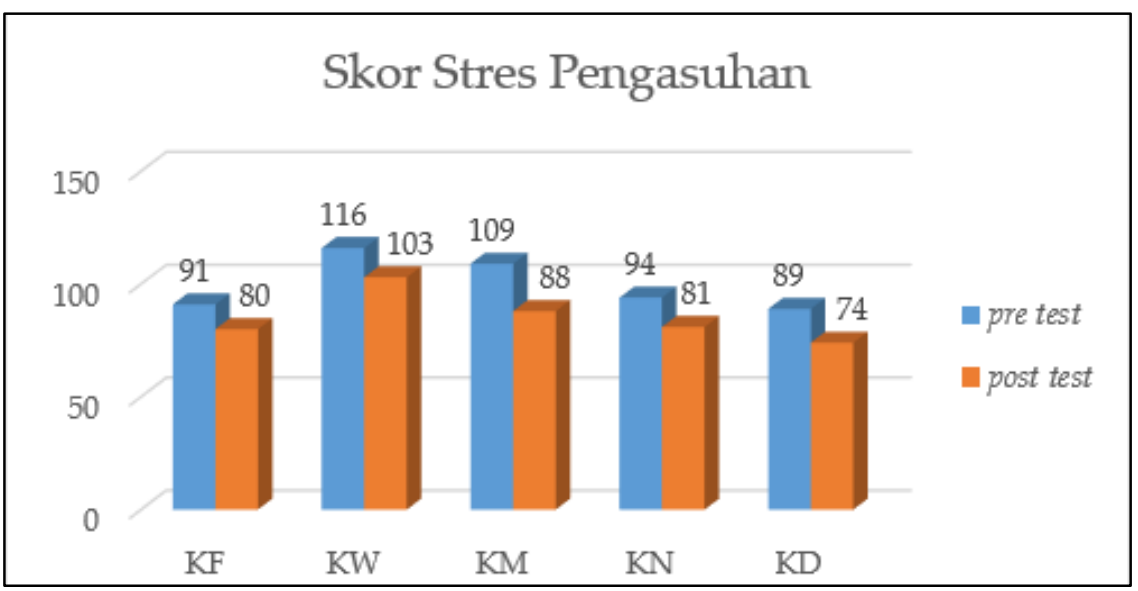

Gambar 1. Skor stres pengasuhan partisipan

nurunan stres pengasuhan pada partisipan setelah mengikuti program "KOMPAK". Penurunan skor stres pengasuhan pada partisipan dapat menjadi penanda bahwa perlakuan telah berhasil diberikan dan memengaruhi kondisi stres partisipan. Keberhasilan pemberian perlakuan juga dilihat dari penilaian observer pada lembar indikator keberhasilan.

\section{Indikator keberhasilan Program "KOMPAK"}

Indikator keberhasilan tujuan program intervensi dinilai berdasarkan hasil observasi dari indikator ketercapaian tujuan program intervensi. Hasil observasi indikator keberhasilan program dianalisis menggunakan metode Cohen's Kappa untuk melihat kesepakatan antar 2 rater. Hasil yang reliabilitas yang didapatkan antar rater yaitu $K=1,000$, dengan asumsi standard error 0,000 . Hal ini menunjukkan bahwa tingkat reliabilitas antar rater masuk dalam kategori baik (almost perfect agreement), dengan standar error yang kecil sehingga semakin reliabel hasil pengukuran yang dihasilkan (Landis \& Koch, 1977).

Peneliti kemudian menganalisis keseluruhan penilaian observer dengan menggunakan rumus persentase keberhasilan untuk mengetahui sejauh mana proses program yang dilakukan telah berjalan sesuai dengan tujuan. Hasil analisis menunjukkan bahwa proses terapi telah mencapai $91,43 \%$ dari indikator 
keberhasilan program sehingga dapat disimpulkan bahwa intervensi atau manipulasi yang diberikan telah sesuai dengan rancangan penelitian.

\section{Uji hipotesis}

Pergerakan perubahan skor kualitas hidup partisipan sebelum dan sesudah perlakuan dapat dilihat pada tabel 2.

Berdasarkan tabel 2 dan gambar 2 dapat diketahui bahwa terdapat peningkatan skor kualitas hidup sebelum dan sesudah pemberian perlakuan pada partisipan dari 99,4 menjadi 110,6. Peneliti kemudian melakukan uji hipotesis untuk melihat perubahan skor pada pengukuran pretest dan postest yang terjadi secara statistik dengan menggunakan Wilcoxon signed-rank test.

Tabel 3 menunjukan ranking negatif berjumlah 0 , hal ini mengindikasikan bahwa tidak terjadi penurunan pada skor partisipan sesudah perlakuan (posttest) dibandingkan dengan sebelum diberikan perlakuan (pretest). Pada tabel di atas juga menunjukan ranking positif yang berjumlah 5, hal ini mengindikasikan bahwa skor partisipan mengalami kenaikan setelah diberikan perlakuan (posttest) dibandingkan sebelum diberikan perlakuan (pretest). Pada kolom seri menunjukan angka 0 , hal ini mengindikasikan bahwa tidak ada skor partisipan sebelum perlakuan (pretest) dan sesudah perlakuan yang memiliki nilai yang sama.

Tabel 2.

Hasil Pretest dan Posttest Skor Kualitas Hidup

\begin{tabular}{ccc}
\hline \multirow{2}{*}{ Inisial } & \multicolumn{2}{c}{ Skor Kualitas Hidup } \\
\cline { 2 - 3 } & Pretest & Posttest \\
KF & 104 & 113 \\
KW & 94 & 102 \\
KM & 103 & 116 \\
KN & 101 & 108 \\
KD & 95 & 114 \\
\hline Rerata & $\mathbf{9 9 , 4}$ & $\mathbf{1 1 0 , 6}$ \\
\hline
\end{tabular}

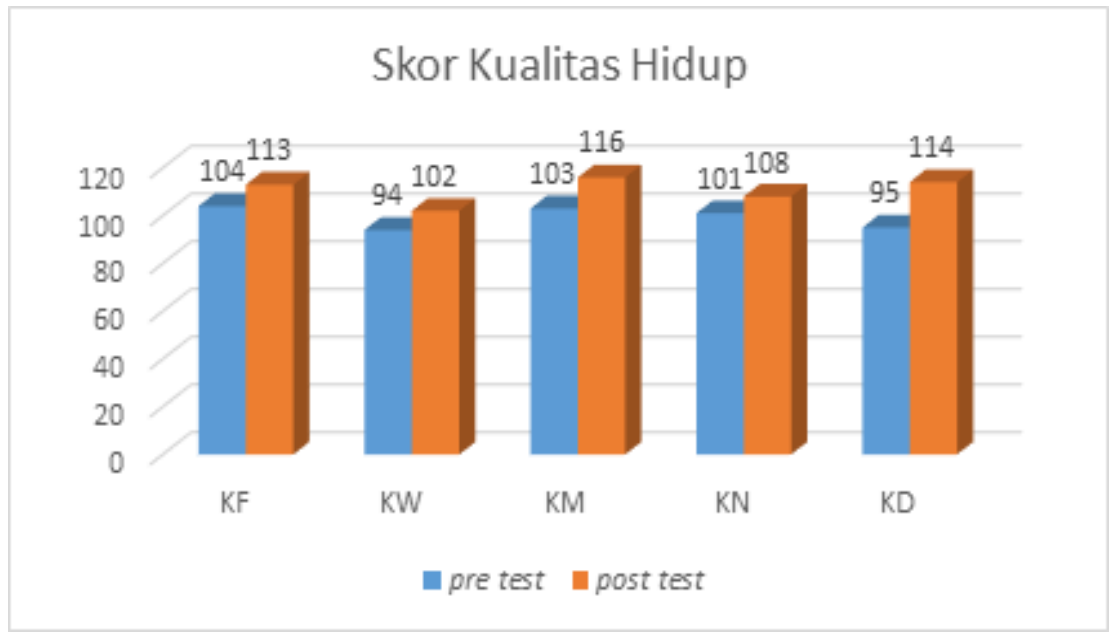

Gambar 2. Grafik perubahan skor kualitas hidup partisipan 
Tabel 3.

Ranking Uji Hipotesis Signed-rank Wilcoxon

\begin{tabular}{llccc}
\hline & & $N$ & Rerata Ranking & Jumlah Ranking \\
\hline Posttest - & Ranking negatif & 0 & 0,00 & 0,00 \\
pretest & Ranking positif & 5 & 3,00 & 15,00 \\
& Seri & 0 & & \\
& Total & 5 & & \\
\hline
\end{tabular}

Berdasarkan uji hipotesis menggunakan uji signed-rank Wilcoxon, hasil analisis menunjukkan bahwa terdapat perbedaan yang signifikan antara skor pretest dan posttest pada kualitas hidup partisipan dengan nilai $Z=-2,023 ; p=0.043$ $(p>0,05)$. Hal ini mengindikasikan bahwa terdapat peningkatkan kualitas hidup yang signifikan setelah partisipan diberikan perlakuan. Rerata skor kualitas hidup mengalami peningkatan setelah partisipan mengikuti program "KOMPAK".

Berdasarkan hasil uji hipotesis yang telah dilakukan dapat disimpulkan bahwa seluruh partisipan yang berjumlah 5 orang mengalami peningkatan skor kualitas hidup yang signifikan setelah pemberian perlakuan. Hal ini menujukan bahwa $\mathrm{Ha}$ diterima dan Ho ditolak, yang artinya hipotesis penelitian diterima. Program "KOMPAK" dapat meningkatkan kualitas hidup ibu pasien kanker anak.

\section{Diskusi}

Hipotesis yang diajukan pada penelitian ini yaitu program "KOMPAK" diharapkan mampu meningkatkan kualitas hidup ibu pasien kanker anak. Berdasarkan hasil uji hipotesis dengan menggunakan uji signedrank Wilcoxon menunjukkan bahwa terdapat perbedaan yang signifikan antara skor partisipan sebelum diberikan perlakuan (pretest) dengan skor partisipan setelah diberikan perlakuan (posttest) sebesar
$Z=-2,023$ dan signifikansi sebesar $p=0,043$ $(p>0,05)$. Adanya peningkatan pada kualitas hidup seluruh partisipan menandakan bahwa program "KOMPAK" mampu untuk meningkatkan kualitas hidup ibu pasien kanker anak.

Program "KOMPAK" merupakan program yang disusun menggunakan aspek dukungan sosial yaitu dukungan informasi, dukungan emosional dan pernghargaan serta dukungan persahabatan (dalam Sarafino \& Smith, 2011). Program "KOMPAK" diberikan kepada partisipan dalam bentuk kelompok. Melalui dukungan yang diperoleh dalam kelompok para partisipan diharapkan mendapatkan dukungan melalui berbagai dengan sesama, mendapatkan informasi, dan memberikan kesempatan untuk saling membantu. Hal ini sejalan dengan yang diungkapkan oleh Yalom (dalam Varcarolis \& Halter, 2010) bahwa dukungan yang diperoleh dari kelompok memiliki fungsi informasi dan pembelajaran. Proses tersebut terjadi ketika partisipan dalam kelompok berbagi pengalamannya dan menjadi pengetahuan baru bagi anggota lainnya. Sarafino (1998) mengungkapkan bahwa ketika menghadapi keadaan penuh stres yang terkait dengan penyakit kronis, dukungan yang paling banyak dibutuhkan adalah dukungan emosi dan penghargaan serta dukungan informasi.

Peningkatan yang terjadi pada kualitas hidup seluruh partisipan didukung oleh penurunan stres pengasuhan yang 
dirasakan oleh partisipan. Pada penelitian ini, peneliti juga melihat skor stres pengasuhan partisipan sebelum dan sesudah diberikan perlakuan. Hasil yang diperolah menunjukan bahwa terjadi perubahan skor sebesar $Z=-2,032, p=0,042$ $(p<0,05)$. Kondisi ini menunjukan selain dapat meningkatkan kualitas hidup seseorang, program "KOMPAK" juga mampu menurunkan stres pengasuhan partisipan. Partisipan yang mendapatkan program "KOMPAK" mengalami penurunan pada aspek stres pengasuhan yang kemudian menyebabkan terjadinya peningkatan pada kualitas hidup mereka. Stres pengasuhan memiliki hubungan yang signifikan dengan kualitas hidup. Hal ini sejalan dengan penelitian yang dilakukan oleh Maryanti (2017) yang menyebutkan bahwa terdapat hubungan yang signifikan antara stres pengasuhan dengan kualitas hidup orang tua, semakin tinggi stres pengasuhannya maka kualitas hidupnya pun semakin rendah.

Stres pengasuhan pada partisipan mengalami penurunan karena adanya dukungan sosial yang diperoleh dari partisipan lain selama program "KOMPAK" berlangusng. Menurut McGrath (2001), para orang tua pasien leukemia membutuhkan dukungan selama proses pengobatan anaknya berlangsung. Dukungan ini dapat diberikan oleh pasangan, keluarga, teman atau sahabat, perawat atau petugas media rumah sakit. Menurut Johnson dan Johnson (2009), dukungan sosial dapat meningkatkan kesejahteraan psikologis seseorang dan mampu mengatasi stres yang sedang dialami oleh seseorang.

Dukungan sosial yang merupakan landasan teori dari pembuatan program "KOMPAK" yang diterjemahkan oleh peneliti dalam beberapa kegiatan yaitu psikoedukasi, sharing dan diskusi mengenai kondisi anak dan kondisi diri selama mendampingi anak, pelatihan keterampilan memecahkan masalah dan pemberian relaksasi. Seluruh kegiatan telah diberikan kepada partisipan yang ditunjukan melalui hasil cek manipulasi.

Dukungan informasi diberikan kepada partisipan dalam bentuk pemberian informasi yang diberikan oleh dokter, fasilitator dan antara partisipan. Pemberian informasi dari dokter berupa psikoedukasi dengan pemberian materi mengenai kanker anak, kemudian dilanjutkan pemberian materi dari fasilitator terkait bagaimana dampak kanker pada kondisi psikologis anak dan orang tua, cara mengenali diri, mengelola stres dan relaksasi. Informasi yang didapatkan melalui partisipan lain terjadi saat para partisipan saling bertukar informasi dan pengalaman yang mereka alami. Melalui ketiga hal tersebut, partisipan merasakan bahwa mendapat tambahan pengetahuan, pemahaman dan solusi untuk mengatasi masalah yang dihadapi melalui informasi yang diterima dari dokter, fasilitator maupun dari partisipan lain. Partisipan juga dapat belajar melalui pengalaman partisipan lain.

Pemberian dukungan informasi melalui psikoedukasi dirasakan banyak manfaatnya oleh masing-masing partisipan. Saat penyampaian materi oleh dokter seluruh partisipan merasa antusias. Hal-hal yang partisipan tanyakan kepada dokter yaitu terkait makanan yang tidak boleh anak mereka konsumsi dan efek samping dari pengobatan. Para partisipan mengaku sangat terbantu dengan informasi yang disampaikan oleh dokter terutama mengenai informasi tentang pengonsumsian cokelat. Partisipan KN mengaku sangat senang dengan informasi yang ia dapatkan 
dari dokter karena selama ini ia sering melarang anaknya untuk makan cokelat. Pemberian psikoedukasi memiliki tujuan untuk memberikan pengetahuan terkait dengan terapi yang akan dilakukan dan permasalahan yang sedang dialami (Wilding \& Milne, 2008). Hal ini juga sejalan dengan Supraktiknya (2011) yang menyebutkan bahwa dengan memberikan psikoedukasi mampu meningkatkan kemampuan kognitif seseorang karena terjadi peningkatan pengetahuan tentang kondisi penyakit.

Aspek dari dukungan sosial yaitu dukungan emosional dan penghargaan. Dukungan emosional terbentuk melalui proses sharing, interaksi partisipan, saling mendengarkan dan memberi dukungan positif di dalam kelompok. Tujuan program antara lain adalah sebagai media untuk memfasilitasi partisipan mengungkapkan perasaan, didengarkan, diperhatikan dan saling membantu. Partisipan merasa hal tersebut sangat membantu membuat perasaan menjadi lebih lega karena dapat saling berbagi dengan individu yang berada pada kondisi yang sama.

Aspek dukungan emosional dan penghargaan dilakukan hampir di seluruh kegiatan yang melibatkan sesi sharing. Pada program "KOMPAK" sesi sharing dibuka pada kegiatan mengenali perubahan psikologis anak dan orang tua. Para partisipan pada sesi ini cukup antuisas menceritakan kondisi anak-anak mereka, bahkan mereka sepakat bahwa kondisi yang paling banyak berubah dari anak mereka yaitu kondisi emosionalnya. Anak KM, KF dan KD sering kali marah-marah dan merengek apabila keinginannya tidak segera dipenuhi oleh orang tuanya. Para ibu merasa khawatir bila tidak segera memenuhi permintaan anaknya karena takut kondisi tersebut dapat memengaruhi kondisi kesehatan anaknya. Ibu lainnya mengeluhkan permasalahan yang berbeda, KW dan KN mengeluhkan anaknya mengalami kesulitan berjalan karena merasakan nyeri pada bagian kakinya.

Melalui sesi mengenali kondisi anak, para ibu merasa terfasilitasi untuk menyampaikan apa yang menjadi kekhawatirannya selama ini. Para partisipan merasa tidak sendiri menghadapi kondisi anaknya yang mengalami perubahan semenjak menjalanakan pengobatan, tetapi ada orang lain juga yang merasakan hal yang sama. Melalui sharing para partisipan merasakan ketenangan dan semangat untuk mendampingi anak mereka menjalankan pengobatan. Adanya dukungan dari orang lain para partisipan menjadi lebih yakin akan kemampuan dirinya (Wilfley, et al., 2002). Menurut Reis et al. (2010) dalam penelitiannya membuktikan bahwa dengan berbagi informasi melalui sharing dengan orang lain dapat menimbulkan perasaan positif, ditambah lagi bila orang lain memberikan respons yang antusias dengan informasi yang disampaikan.

Aspek lain dari dukungan sosial yaitu dukungan persahabatan. Dukungan persahabatan merupakan pelengkap untuk dukungan emosional dan dukungan penghargaan. Dukungan persahabatan melibatkan keberadaan orang lain untuk menghabiskan waktu bersama, memberikan dukungan dan menimbulkan rasa kebersamaan antara partisipan. Pada kegiatan program "KOMPAK" ini partisipan telah saling menghormati dan menerima kondisi partisipan satu sama lain. Di antara partisipan saling memberikan respons yang positif dan memberikan penguatan satu sama lain dan juga dukungan dari fasilitator. Pengalaman yang 
sama antara partisipan satu dengan partisipan lain saling menguatkan diri mereka bahwa mereka menjalani permasalahan ini tidak sendirian.

Pada program "KOMPAK" perasaan saling menguatkan tercipta saat sesi mengenali kondisi dalam diri. Pada sesi ini beberapa partisipan mengungkapkan perasaannya dan kekhawatiran yang sedang saat ini dirasakan. Beberapa partisipan mengungkapkan bahwa dirinya sering kali mengalami kesulitan tidur pada malam hari, tidak nafsu makan dan mengalami beban pikiran yang cukup besar. Hal ini pun dibenarkan oleh partisipan KD sebagai salah satu orang tua yang telah merawat anaknya cukup lama, KD mengaku bahwa diawal dirinya mengetahui anaknya mengidap kanker KD mengalami pergejolakan batin. Sepanjang hari yang ia lakukan hanya menangis, menyalahkan dirinya dan mengabaikan kondisi kesehatannya. KD menceritakan kepada partisipan lain, bahwa dirinya tidak bisa tidur selama sebulan dan berat badannya turun drastis. Namun lambat laun KD menyadari bahwa perilakunya salah, ia menyadari bahwa ia sedih melihat kondisi anaknya tapi ia tidak boleh berlarut-larut. KD sadar bahwa anaknya membutuhkan dirinya dan sejak saat itu KD selalu bersemangat dan ikut menjaga kondisi kesehatannya.

Sharing yang dilakukan oleh KD direspon baik oleh partisipan lain. Partisipan merasa termotivasi dengan apa yang disampaikan oleh KD dan turut merasakan apa yang KD alami. Para partiispan pun menyampaikan apa yang mereka saat ini rasakan baik kesedihan, kekhawatiran dan kegelisahan yang sedang dirasakan. Mengungkapkan perasaan sedih dapat membantu para orang tua dalam mengurangi beban yang mereka rasakan.
Hal tersebut juga mendukung penelitian dari Payne, Lundberg, Brennan, dan Holland (1997) bahwa di dalam sebuah kelompok dukungan, partisipan merasakan berkurangnya rasa kesendirian termasuk juga berkurangnya emosi negatif yang dirasakan.

Pada program "KOMPAK" terdapat materi mengelola stres. Pada kegiatan ini partisipan dibekali cara untuk dapat mengatasi permasalahan yang sedang dihadapi. Saat kegiatan ini berlangsung seluruh partisipan nampak mampu mengelompokkan masalah mereka dengan baik dan kemudian mencoba untuk menyusun cara untuk menyelesaikannya. Partisipan KD merasa bahwa kegiatan pada sesi ini merupakan pengalaman baru yang ia terima. KD mengungkapkan bahwa ilmu yang ia dapat pada kegiatan ini dapat menjadi cara baru yang dapat digunakan untuk menyelesaikan masalahnya. Tujuan diberikannya kegiatan mengelola stres untuk melatih kemampuan pemecahan masalah yang dimiliki oleh partisipan (Bransford \& Stein, 1993). Partisipan juga mampu mengidentifikasi masalah dan mendapatkan alternatif solusi dari permasalahan yang sedang dihadapi (Northouse, Katapodi, Song, Zhang, \& Mood, 2010)

Kegiatan lain yang diberikan kepada klien yaitu relaksasi. Pada sesi relaksasi hampir seluruh partisipan mampu mengikuti instruksi dengan baik. Relaksasi yang diberikan mulai relaksasi pernapasan kemudian dilanjutkan dengan relaksasi otot tangan, pundak, dan kaki. Partisipan merasakan sedikit kelegaan dan ketegangan yang dirasakan pada otot pundak sedikit berkurang setelah mengikuti sesi relaksasi ini. Sesi relaksasi yang diberikan agar dapat membantu partisipan untuk mengurangi 
ketegangan (Corey, 2012), menurunkan stres (Anggraieni \& Subandi, 2014; Subekti \& Utami, 2011), dan menurunkan kecemasan (Sari \& Subandi, 2015).

Seluruh kegiatan pada program "KOMPAK" telah diberikan dan diikuti dengan baik oleh seluruh peserta. Melalui hasil wawancara setelah program "KOMPAK" diberikan, masing-masing partisipan merasakan manfaat yang berbeda-beda. Partisipan KF merasa dari keseluruhan kegiatan yang diberikan sesi yang paling ia sukai yaitu sesi ketiga mengenali diri sendiri dan mengelola stres. Berbeda dengan KF, KW dan KM merasa relaksasi salah satu kegiatan yang mereka sukai dan bermanfaat bagi tubuh mereka. Partisipan KD dan KN merasa mengelola stres dengan mengelompokan masalah merupakan sesi yang bermanfaat bagi mereka. Meskipun merasakan manfaat yang berbeda-beda dari keseluruhan sesi yang diberikan terdapat kesamaan yang dirasakan oleh keseluruh partisipan yaitu dari metode sharing yang sebagian besar digunakan pada kegiatan ini.

Melalui sharing para partisipan mendapatkan banyak pengetahuan, ilmu baru, merasa tidak sendirian dan akhirnya berdampak pada rasa lega yang mereka rasakan. Para partisipan juga diberikan kebebasan untuk menyampaikan apa yang mereka rasakan yang membuat mereka bisa meluapkan kesedihan, kekhawatiran dan kegelisahan yang mereka rasakan saat ini. Di dalam sharing memungkinkan terjadinya interaksi di antara partisipan dan antara partisipan dengan fasilitator kelompok. Latar belakang partisipan yang berbeda yaitu lama mendampingi anak menyebabkan proses pertukaran informasi menjadi menarik. Partisipan yang telah lebih lama mendampingi anak dapat membagikan pengalamannya pada partisipan yang masih baru dalam mendampingi anak. Orang tua yang masih baru dapat belajar dari orang tua yang sudah lebih lama menjalani pengobatan.

Berdasarkan pendapat dari seluruh partisipan dapat disimpulkan bahwa seluruh kegiatan yang disusun pada modul program "KOMPAK" memiliki manfaat yang berbeda-beda pada kondisi partisipan, sehingga untuk pemberian selanjutnya agar mendapatkan hasil efektif disarankan untuk menggunakan keseluruhan kegiatan yang ada di program "KOMPAK" dan mengutamakan interaksi yang terjadi pada partisipan dalam sesi sharing.

Penelitian ini menunjukan hasil bahwa program "KOMPAK" mampu menurunkan stres pengasuhan dan meningkatkan kualitas hidup partisipan serta hampir seluruh kegiatan memiliki manfaat bagi partisipan. Meskipun demikian, hasil analisis per dimensi kualitas hidup terjadi penurunan pada dimensi coping pada partisipan padahal program "KOMPAK" telah dilengkapi cara mengelola stres. Saat follow up dilakukan, partisipan mengaku bahwa cara yang mereka dapatkan pada kegiatan program "KOMPAK" merupakan cara yang baik dan berguna bagi mereka akan tetapi hal tesebut tidak mudah untuk dilakukan. Partisipan membutuhkan waktu untuk bisa berlatih mengelola stresnya dengan menggunakan cara tersebut.

Bila dibandingkan dengan penelitian sebelumnya yang dilakukan oleh Swastiningsih (2009), penelitian ini mampu membuktikan program kelompok dukungan orang tua yang telah dimodifikasi menjadi program "KOMPAK" tidak hanya mampu menurunkan stres ibu pasien kanker anak tetapi juga terbukti mampu meningkatkan kualitas hidup ibu pasien 
kanker anak. Tidak hanya itu, kelebihan penelitian ini dibandingkan dengan penelitian sebelumnya yaitu pada pemberian materi yang dilengkapi dengan cara mengelola stres dengan belajar mengelompokan masalah dan mencoba menyusun strategi untuk memecahkan masalah yang tidak ada pada modul sebelumnya. Sesi ini dirasakan sangat bermanfaat oleh partisipan, mereka mendapatkan ilmu baru dari sesi mengelola stres ini.

Selama proses perlakuan diberikan terdapat beberapa evaluasi diantaranya kesulitan peneliti untuk menentukan waktu yang tepat untuk dilakukan follow up karena beberapa partisipan tidak tinggal di Yogyakarta dan jadwal pengobatan yang belum dapat dipastikan. Hal ini mneyebabkan proses follow up tidak dilakukan secara bersama-sama. Keterbatasan penelitian ini terletak pada validitas eksternalnya, dimana pada penelitian one group pretest-posttest design, hasil penelitian tidak dapat digeneralisasikan. Keterbatasan lainnya yaitu tidak dilakukan pengukuran ulang pada saat follow up sehingga tidak ada jaminan bahwa perlakuan yang diberikan dapat bertahan dalam waktu cukup lama setelah perlakuan selesai diberikan serta pemilihan kondisi partisipan yang berada pada kategori sedang. Disarankan untuk mencari partisipan yang memiliki kategori kualitas hidup pada kategori sedang, dan stres pengasuhan pada kategori tinggi untuk mengurangi terjadinya ceiling effect pada penelitian.

\section{Kesimpulan}

Program "KOMPAK" terbukti efektif untuk meningkatkan kualitas hidup ibu pasien kanker anak. Hal tersebut juga didukung oleh data kualitatif yang diperoleh bahwa partisipan merasakan program yang diikuti sangat bermanfaat dan membantu ketika menghadapi permasalahan, dapat mengungkapkan perasaan yang dipendam dan mendapatkan dukungan atau bantuan baik dari sesama partisipan maupun dari fasilitator. Manfaat penelitian dapat lebih dirasakan oleh partisipan jika partisipan benar-benar mempraktikkan materi yang telah diajarkan pada kesehariannya.

Saran

Peneliti lainnya yang ingin melakukan penelitian dengan menggunakan modul program "KOMPAK" pada karakteristik partisipan yang sama disarankan untuk memperhatikan waktu pelaksanaan. Sebaiknya pelaksanaan disesuaikan dengan jadwal pengobatan dari masing-masing anak sehingga pemberian kegiatan dalam dilakukan dengan optimal. Peneliti selanjutnya mungkin bisa mempertimbangan partisipan lain sebagai partisipan penelitian seperti ayah atau saudara kandung pasien kanker anak.

Pada penelitian ini partisipan yang diberikan perlakukan merupakan partisipan yang memiliki skor kualitas hidup dan stres pengasuhan yang berada pada kategori sedang. Hal ini menyebabkan kurang terlihatnya dampak dari perlakukan terhadap peningkatan yang dialami peserta karena kondisi peserta yang berada pada kategori yang cukup baik. Disarankan pada penelitian berikutnya menggunakan partisipan yang memiliki skor kualitas hidup dan stres pengasuhan yang berada pada kategori rendah pada kualitas hidup dan tinggi pada stres pengasuhan agar hasil perlakukan dapat terlihat lebih jelas. 
Selain itu, pada penelitian ini kegiatan follow up dilakukan tanpa memberikan kembali skala pengukuran untuk melihat kondisi partisipan setelah kegiatan berakhir, disarankan peneliti berikutnya dapat melakukan pengukuran kembali saat follow up untuk melihat konsistensi kondisi partisipan setelah perlakuan diberikan.

\section{Kepustakaan}

Ahern, L. S. (2005). Psychometric properties of the parenting stress index- short form (Tesis tidak dipublikasikan). North Carolina State University, Raleigh.

Anggraieni, W. N., \& Subandi, S. (2014). Pengaruh terapi relaksasi zikir untuk menurunkan stres pada penderita hipertensi esensial. Jurnal Intervensi Psikologi, 6(1), 81-102. doi: 10.20885/intervensipsikologi.vol6.iss1. art6

Awasthi, P., \& Kuhu (2017). The cancer disaster: Psychology of informal caregivers. Jurnal of Psychology and Clinical Psychiatry 7(1), 00424. doi: 10.15406/jpcpy.2017.07.00424

Bransford , J. \& Stein, B. S. (1993). The IDEAL problem solver: A guide for improving thinking, learning, and creativity (Edisi kedua). New York: W.H. Freeman.

Brown, R. T. (Ed.). (2006). Comprehensive handbook of childhood cancer and sickle cell disease: A biopsychosocial approach. New York: Oxford University Press.

Corey, G. (2012). Theory and practice of counseling and psychotherapy (Edisi kedelapan). California: Brooks/Cole, Cengage Learning

Dardas, L. A., \& Ahmad, M. M. (2014). Quality of life among parents of children with autistic disorder: A sample from the Arab world. Research in Developmental Disabilities, 35(2), 278-287. doi: $\underline{10.1016 / j . r i d d .2013 .10 .029}$

Frank, N. C., Brown, R. T., Blount, R. L., \& Bunke, V. (2001). Predictors of affective responses of mothers and fathers of children with cancer. Psycho-Oncology, 10(4), 293-304. doi: 10.1002/pon.526

Hidayati, F. (2013). Pengaruh pelatihan" Pengasuhan Ibu Cerdas" terhadap stres pengasuhan pada ibu dari anak autis. Psikoislamika: Jurnal Psikologi dan Psikologi Islam, 10(1), 22-29. doi: 10.18860/psi.v10i1.6359

Johnson, D. W., \& Johnson, F. P. (2009). Joining together, group theory and group skills (Edisi keempat). Allyn and Bacon.

Khoury, M. N., Huijer, H. A. S., \& Doumit, M. A. A. (2013). Lebanese parents' experiences with a child with cancer. European Journal of Oncology Nursing, 17(1), 16-21. doi: 10.1016/j.ejon.2012.02.005

Lähteenmäki, P. M., Sjöblom, J., Korhonen, T., \& Salmi, T. T. (2004). The life situation of parents over the first year after their child's cancer diagnosis. Acta Paediatrica, 93(12), 1654-1660. doi: 10.1111/j.16512227.2004.tb00858.x

Landis, J. R., \& Koch, G. G. (1977). An application of hierarchical kappa-type statistics in the assessment of majority agreement among multiple observers. Biometrics, 363-374. doi: 10.2307/2529786

LeSeure, P., \& Chongkham-Ang, S. (2015). The experience of caregivers living with cancer patients: A systematic review and meta-synthesis. Journal of Personalized Medicine, 5(4), 406-439. doi: 10.3390/jpm5040406 
Lestari, S.( 2012). Psikologi Keluarga. Jakarta: Kencana

Maryanti, N. C. W., (2017). Hubungan antara stres pengasuhan dan penerimaan orangtua terhadap kualitas hidup pada ibu dengan anak gangguan spektrum autisme. (Tesis tidak dipublikasikan). Universitas Gadjah Mada, Yogyakarta.

McGrath, P. (2001). Identifying support issues of parents of children with leukemia. Cancer practice, 9(4), 198-205. doi: 10.1046/j.1523-5394.2001.94008.x

Minaya, P., Baumstarck, K., Berbis, J., Goncalves, A., Barlesi, F., Michel, G., ... \& Bladou, F. (2012). The CareGiver Oncology Quality of Life Questionnaire (CarGOQoL): Development and validation of an instrument to measure the quality of life of the caregivers of patients with cancer. European Journal of Cancer, 48(6), 904-911. doi: 10.1016/j.ejca.2011.09.010

Lambrini, K., Christos, I., Alexandros, M., \& Aikaterini, F. (2015). Families of children with cancer. Scholars Journal of Applied Medical Sciences, 3(1F), 440-443.

Nayak, M. G., George, A., Vidyasagar, M. S., \& Kamath, A. (2014). Quality of life of family caregivers of patients with advanced cancer. Journal of Nursing and Health Science, 3(2), 70-75.

Northouse, L. L., Katapodi, M. C., Song, L., Zhang, L., \& Mood, D. W. (2010). Interventions with family caregivers of cancer patients: meta-analysis of randomized trials. CA: A Cancer Journal for Clinicians, 60(5), 317-339. doi: 10.3322/caac. 20081

Payne, D. K., Lundberg, J. C., Brennan, M. F., \& Holland, J. C. (1997). A psychosocial intervention for patients with soft tissue sarcoma. Psycho-Oncology, 6, 65-
71. doi: 10.1002/(SICI)10991611(199703)6:1\%3C65::AIDPON236\%3E3.0.CO;2-2

Pisula, E., \& Porębowicz-Dörsmann, A. (2017). Family functioning, parenting stress and quality of life in mothers and fathers of Polish children with high functioning autism or Asperger syndrome. PloS one, 12(10). doi: 10.1371/journal.pone.0186536

Reis, H. T., Smith, S. M., Carmichael, C. L., Caprariello, P. A., Tsai, F. F., Rodrigues, A., \& Maniaci, M. R. (2010). Are you happy for me? How sharing positive events with others provides personal and interpersonal benefits. Journal of Personality and Social Psychology, 99(2), 311-329. doi: 10.1037/a0018344

Sarafino, E. P. (1998). Health psychology: Biopsychosocial interaction (Edisi ketiga). New York: John Wiley \& Sons, Inc.

Sarafino, E., \& Smith, T. (2011). Health psychology: Biopsychosocial interaction. New Jersey: John Wlley \& Sons, Inc.

Sari, A. D. K., \& Subandi. (2015). Pelatihan teknik relaksasi untuk menurunkan kecemasan pada primary caregiver penderita kanker payudara. Gadjah Mada Journal of Professional Psychology 1(3), 173-192. doi: 10.22146/gamajpp.9393

Sloper, P. (2000). Predictors of distress in parents of children with cancer: A prospective study. Journal of Pediatric Psychology, 25(2), 79-91. doi: 10.1093/jpepsy/25.2.79

Subekti, T., \& Utami, M. S. (2011). Metode relaksasi untuk menurunkan stres dan keluhan tukak lambung pada penderita tukak lambung kronis. Jurnal Psikologi, 38(2), 147-163. 
doi: 10.22146/jpsi.7649

Supratiknya, A. (2011). Merancang program dan modul psikoedukasi. Universitas Sanata Darma. Yogyakarta.

Swastiningsih, N. (2009). Kelompok dukungan orangtua untuk menurunkan tingkat stres orangtua pasien kanker anak (Tesis tidak dipublikasikan). Universitas Gadjah Mada, Yogyakarta.

Varcarolis, E.M., \& Halter, M.J. (2010). Foundations of psychiatric mental health nursing: a clinical approach (Edisi keenam). Missouri: Sauders Elsevier

Wilding, C \& Milne, A. (2013). Cognitive behavioural therapy. Jakarta: PT. Indeks.

Wilfley, D. E., Welch, R. R., Stein, R. I., Spurrell, E. B., Cohen, L. R., Saelens, B. E., ... \& Matt, G. E. (2002). A randomized comparison of group cognitivebehavioral therapy and group interpersonal psychotherapy for the treatment of overweight individuals with binge-eating disorder. Archives of General Psychiatry, 59(8), 713-721. doi: 10.1001/archpsyc.59.8.713

Winarsih. (2015). Gambaran kualitas hidup keluarga pasien kanker yang menjalani kemoterapi di RSUP dr. Karyadi Semarang (Skripsi tidak dipublikasikan). Universitas Diponegoro, Semarang.

Wong, M. Y. F., \& Chan, S. W. C. (2006). The qualitative experience of Chinese parents with children diagnosed of cancer. Journal of Clinical Nursing, 15(6), 710-717. doi: 10.1111/j.13652702.2006.01297.x 